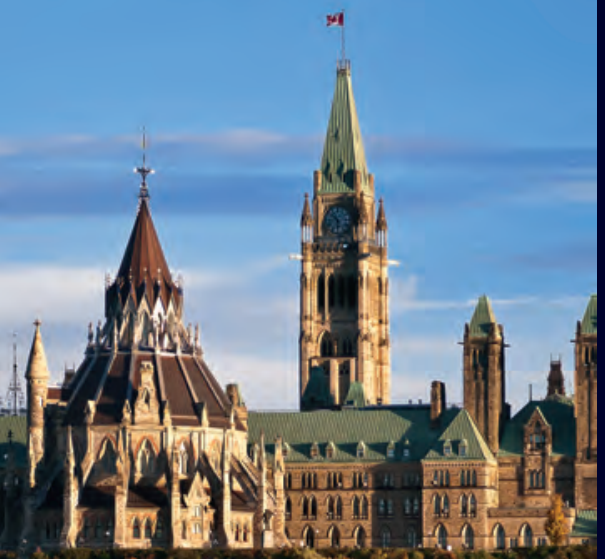

institut C.D. HOWE institute

\author{
COMMENTARY
}

NO. 441

\title{
Mortgaged to the Hilt: Risks From The Distribution of
} Household Mortgage Debt

The financial risks posed by rising levels of household mortgage debt in Canada are best assessed by a focus on the distribution of that debt by income, region and age. The finding: vulnerable pockets exist of excessive leverage or risk.

Craig Alexander and Paul Jacobson 


\section{THE INSTITUTE'S COMMITMENT TO QUALITY}

\section{ABOUT THE AUTHORS}

Craig Alexander

is Vice President, Economic Analysis at the C.D. Howe Institute.

Paul Jacobson is a Consulting Economist at Jacobson Consulting Inc.

Commentary No. 441

December 2015

Financial Services and Regulation
C.D. Howe Institute publications undergo rigorous external review by academics and independent experts drawn from the public and private sectors.

The Institute's peer review process ensures the quality, integrity and objectivity of its policy research. The Institute will not publish any study that, in its view, fails to meet the standards of the review process. The Institute requires that its authors publicly disclose any actual or potential conflicts of interest of which they are aware.

In its mission to educate and foster debate on essential public policy issues, the C.D. Howe Institute provides nonpartisan policy advice to interested parties on a non-exclusive basis. The Institute will not endorse any political party, elected official, candidate for elected office, or interest group.

As a registered Canadian charity, the C.D. Howe Institute as a matter of course accepts donations from individuals, private and public organizations, charitable foundations and others, by way of general and project support. The Institute will not accept any donation that stipulates a predetermined result or policy stance or otherwise inhibits its independence, or that of its staff and authors, in pursuing scholarly activities or disseminating research results.
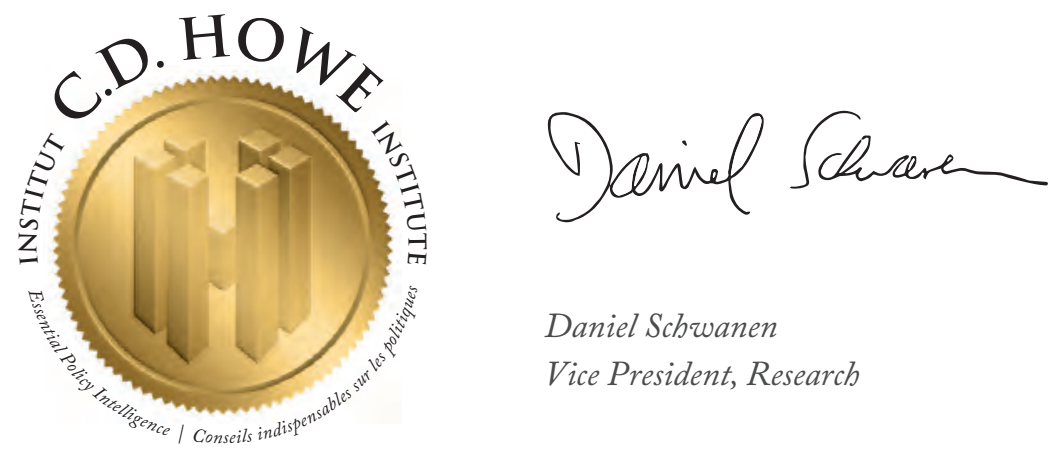

Daniel Schwanen

Vice President, Research 


\section{THE STUDY IN BRIEF}

The rising level of household debt in Canada has raised concerns that a future deleveraging could pose a threat to the economy. In this Commentary, we look behind the aggregate numbers on household mortgage debt to find pockets of vulnerability that raise warning flags. We focus on the distribution of household mortgage debt by income, age and region, which is of critical importance when gauging the risk from the increase in mortgage debt.

Our analysis suggests that primary mortgage debt relative to after-tax income has increased, with a significant minority of Canadians having taken on a high degree of financial risk. The percent of mortgage indebted households with a primary mortgage debt-to-disposable income ratio in excess of 500 percent has climbed from 3 percent in 1999 to 11 percent in 2012. That is far from the majority of Canadians, but it does represent half a million households.

We find the increase in highly mortgage-indebted households has been in all income groups, but more so in lower-income quintiles. The increase in financial risk is also evident across all age groups, but more so for younger Canadians who have entered the market most recently. As one might expect, there has been greater concentration of mortgage debt in the provinces with the strongest housing booms.

When an evaluation is made of mortgage debt relative to accessible financial assets, most Canadians look secure. But, there is a significant minority at risk. Roughly 1-in-5 of mortgage indebted households have less than $\$ 5,000$ in financial assets to draw upon in response to a loss of income or to higher debt service costs. 1-in-10 mortgage-indebted households have less than \$1,500 in financial assets to address any shock. This represents an inadequate financial buffer, as the Statistics Canada Survey of Household Spending indicates that average mortgage payments are more than $\$ 1,000$ a month, before taxes and operating costs.

The data suggest that the majority of Canadians have been responsible in their borrowing, but the sustained low interest-rate environment has encouraged a significant minority to take on considerably more mortgage debt relative to after-tax income. And, it is evident that there are particular pockets of excessive leverage or risk. Beyond risks related to mortgage default, higher debt-to-disposable income ratios can pose economic risks as higher ratios have been associated internationally with larger falls in consumption during difficult economic times. The federal government may want to consider further policy actions to lean against the shift towards significantly higher mortgage burdens. However, such policy measures should not be unduly heavy handed and should be targeted to address the distributional nature of the risks.

C.D. Howe Institute Commentary $($ is a periodic analysis of, and commentary on, current public policy issues. James Fleming edited the manuscript; Yang Zhao prepared it for publication. As with all Institute publications, the views expressed here are those of the authors and do not necessarily reflect the opinions of the Institute's members or Board of Directors. Quotation with appropriate credit is permissible.

To order this publication please contact: the C.D. Howe Institute, 67 Yonge St., Suite 300, Toronto, Ontario M5E 1J8. The full text of this publication is also available on the Institute's website at www.cdhowe.org. 


\section{The relentless rise is household debt is well documented and it has fueled concerns that a future deleveraging by households and credit tightening by lenders could pose a threat to the economy. ${ }^{1}$}

The purpose of this paper is to examine the accumulation of mortgage debt on household balance sheets, but also demonstrate that it is the distribution of the debt, by income, age and region, that matters most when evaluating the economic risks.

By many measures, Canadian household finances are not flashing warning lights. While household debt has increased significantly, close to two-thirds of that borrowing has been through mortgages that have purchased an appreciating real estate asset, which has helped to boost the net worth of many Canadians. The rise in home prices has been key in limiting the degree of leverage (assets relative to liabilities) in household balance sheets. Moreover, Statistics Canada data show that total debt service costs have not climbed significantly because the financial burden of more debt has been largely offset by lower interest rates. It is also encouraging that the federal government's tightening of mortgage insurance rules in recent years, combined with increased regulatory guidance by the Office of the Superintendent of Financial Institutions (OSFI) - Guidelines B20 and B21 - have acted to temper the pace of debt growth (Schembri 2015).

However, the national averages can mask pockets of vulnerability because the financial health of those with high debt loads is mixed with those with little or no debt. In particular, there are many cases where a primary residence is the major financial liability of a household and is, at the same time, the only significant asset.

Delving into the distribution of mortgage debt can reveal specific vulnerabilities. ${ }^{2}$ Regrettably, official large-survey public statistics on the distribution of household debt are difficult to obtain in a timely fashion and on a time-series basis. However, the Statistics Canada Survey of Financial Security (SFS), a household survey, can provide some important perspectives on how mortgage debt has trended across various income groups, age groups and across regions. The key limitation is that the SFS is done periodically, so data are only available for 1999, 2005 and 2012.

The authors would like to thank several anonymous reviewers, as well as Senior Policy Analyst Jeremy Kronick and members of the Financial Services Research Initiative of the C.D. Howe Institute for comments on earlier drafts. The authors retain responsibility for the views expressed here and any errors.

1 The twin vulnerabilities of elevated household debt and house prices have been analyzed in depth in the Bank of Canada's Financial System Review, in several Bank of Canada Review articles (e.g., Crawford and Faruqui, Winter 2011-12) and speeches (e.g., Schembri 2015).

2 Since 2008, the Bank of Canada has used a micro-simulation model to assess the risks from elevated household debt. The distributional information used in the model allows insight into the most vulnerable segments of Canadian households (Umar Faruqui, Xuezhi Liu and Tom Roberts 2012). This analysis is very useful in gauging the economic and financial risks. Due to limited data availability, most private-sector analysis tends to focus on aggregate statistics. 
For the purposes of this report, the focus is on mortgages for primary dwellings, because secondary properties can be sold to address financial stress without greatly impacting the household's quality of life. We compare the primary mortgage debt to the after-tax income of mortgaged households to allow historical comparisons that eliminate the impact of inflation. The focus is also on the mortgage debtto-after-tax income ratio because households in financial stress first attempt to cover their needs through their after-tax income. ${ }^{3}$

We find that primary mortgage debt relative to after-tax income has increased, with a significant minority of Canadians having taken on a high degree of financial risk. The increase in highly mortgage-indebted households has been in all income groups, but more so in lower income quintiles. The increase in financial risk is also evident across all age groups, but more so for younger Canadians who will have entered the market most recently. As one might expect, there has been greater concentration of mortgage debt in the provinces with the strongest housing booms.

While the metrics suggest some cause for concern, it is important to stress that the primary mortgage debt-to-disposable income ratio is not an ideal measure of risk. It measures the stock of debt to the flow of annual income. To assess the pure degree of mortgage leverage, one needs to examine the value of mortgages compared to the value of assets. On this basis, there has been an increase in leverage across all age groups since 1999, but the rise has been very small because of the increase in home prices. However, there is a significant minority at risk because their holdings of accessible financial assets are limited, as we shall discuss below.
While the vast majority of households will be able to meet their financial obligations, the shift towards a larger segment of highly mortgageindebted households is concerning. This is likely the inevitable outcome of the exceptionally low interest-rate environment. A recent speech by Bank of Canada Governor Poloz stressed that the first line of defence against excess leverage is households and lenders behaving prudently, the second line of defence is regulation, and the last line of defence is monetary policy. This is sensible and, accordingly, the government may want to consider further policy actions to lean against the shift towards significantly higher mortgage burdens. However, such policy measures should not be unduly heavy handed. Potential targeted measures would be to tighten underwriting requirements by lifting required credit scores, capping total debt-service ratios at lower levels, lifting qualifying interest rates when doing income testing, or varying the minimum downpayment by the size of mortgage to target higher-priced markets. Such measures would build on the regulatory tightening already done to date without posing a material threat to Canadian real estate markets.

\section{The Mortgage Debt Boom}

The National Balance Sheet Accounts show the dramatic rise of household mortgage debt growth since 1999, jumping from $\$ 375$ billion to $\$ 1.16$ trillion in 2014. The increasing size of mortgages was clearly tied to rising demand and soaring cost for residential real estate. From 1999 to 2014, national average resale home prices soared by 158 percent, requiring larger mortgages for many buyers.

3 The Bank of England established loan-to-income limits for mortgage lending in 2014 because in the recent crisis, "the share of income attributed to consumption fell sharply for households with higher debt-to-income ratios. In addition, there is evidence internationally that higher household debt to income ratios have been associated with larger falls in consumption" (Bank of England, June 2014, page 9). 
The housing boom has had many desirable economic effects. Home ownership rates have reached record high levels. ${ }^{4}$ Existing owners benefited from the rising wealth associated with increased real estate values. The wealth effect likely contributed to economic growth, as did spending on housing-related items. Jobs were created in the construction and real estate sector and indirect jobs were generated from the housing-related expenditure.

However, there is a dark side to the story. The compound average annual growth in household mortgage debt over this period was 7.3 percent, far exceeding the 4.3 percent growth rate in personal disposable (after-tax) income.

According to the national average data from the National Balance Sheet Accounts, mortgage debt as a share of disposable income climbed from 66 percent in 1999 to 99 percent in 2012 and reached 104 percent in 2014. But, these economywide averages understate the degree of financial risk for those that carried mortgages because they divide the value of mortgages across the income of households with and without mortgages. The SFS data show that primary mortgages have increased significantly. The primary mortgage debt-to-disposable income ratio has climbed from 144 percent of income in 1999 to 204 percent in 2012. However, this also understates the degree of financial risk for a significant minority of households.

The share of exceptionally high mortgageleverage households has increased. This can be seen in the ratio of primary residence mortgage debt to after-tax income across mortgaged households. In 1999, 12.6 percent of households had mortgages that exceeded 300 percent of disposable income (Figure 1). By 2012, the share had reached
27.4 percent. And, the share of households with mortgages at 500 percent or more of disposable income has climbed from 3.4 percent in 1999 to 10.8 percent in 2012 . The underlying story is that as older, smaller mortgages were paid off, they were replaced by larger new mortgages reflecting the increase in home prices that has far outpaced household income growth.

The SFS data also allow a more detailed analysis of primary mortgage trends by income, age and region - all of which will demonstrate how leverage has not only increased, but has become skewed with a rising share of highly mortgage-indebted households.

\section{Mortgage Trends by Income}

Mortgage debt for primary dwellings has increased dramatically in recent years, across all income quintiles, with a marked change in the distribution of mortgage debt within each income group. To show the shift in mortgage borrowing, the figures for 1999 can be adjusted for inflation and expressed in 2012 dollars. The share of households with mortgages above $\$ 99,000$ in 2012 dollars has increased across the entire income spectrum, with households in the fourth and fifth income quintiles - the two highest groups - increasing their share of mortgages above $\$ 200,000$ (Table 1 ).

It is evident that as mortgage size has increased, so too have mortgage debt-to-disposable income ratios for mortgaged households (Table 2). At the lowest quintile, those with mortgage debt have particularly high ratios due to low income. The reverse is true for the top income quintile. The shift for the middle income quintiles is most interesting, as all of their mortgage debt-to-disposable income ratios climbed, reaching four times income for the

4 It should be noted that demographics have played a role in boosting mortgage debt, as a greater share of the population moves to ages associated with high levels of homeownership. (CMHC, 2013) 


\section{Figure 1: Distribution of Mortgage Debt}

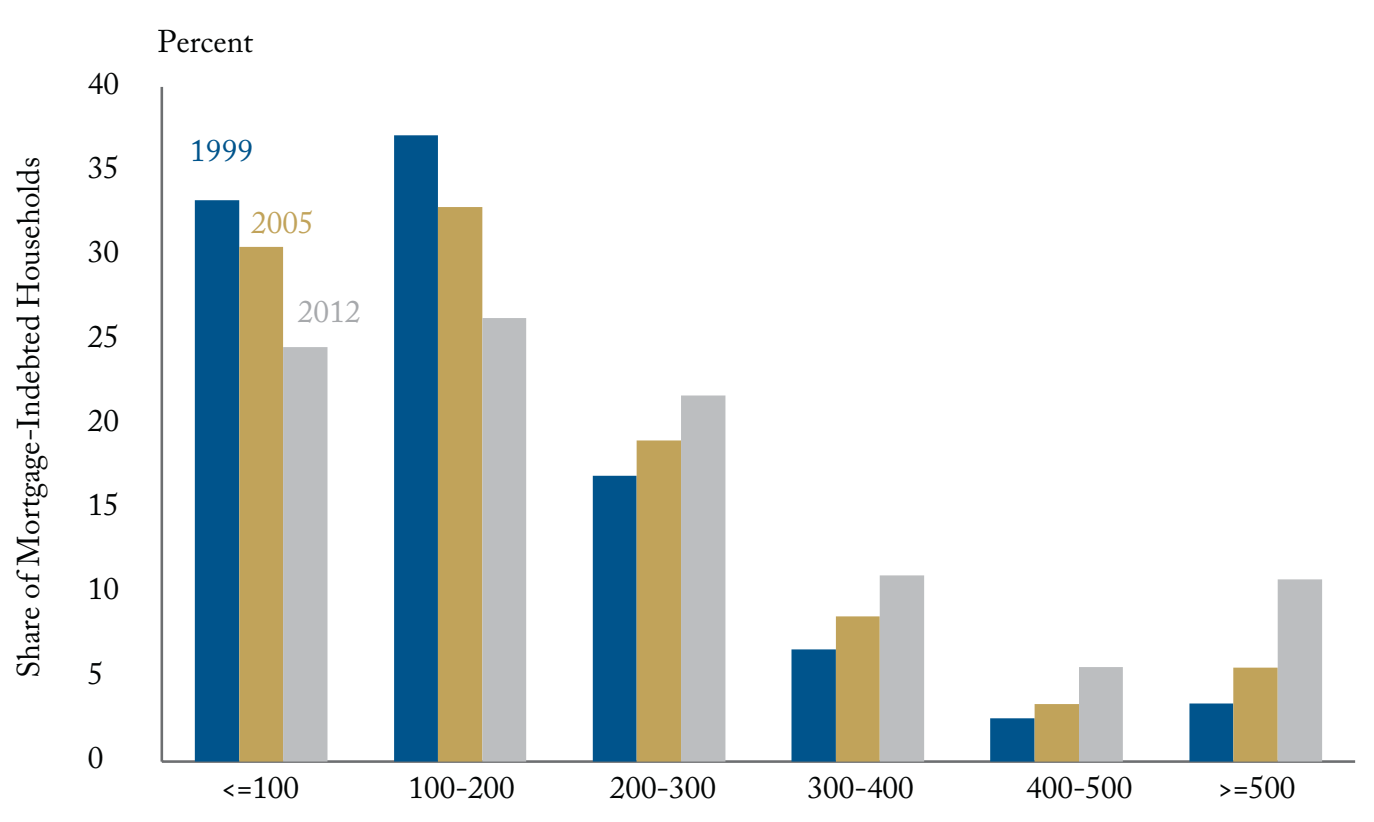

Primary Mortgage Debt to After-tax Income of Mortgaged Households, Percent

Source: Statistics Canada, SFS, 1999, 2005, 2012-JCI.

second quintile, almost three times income for the third quintile and more than two times income in the fourth quintile.

Assessing the degree of risk is problematic, as there is no established economic prescribed limit. However, we could arbitrarily set the definition of high mortgage-indebted households as those with a debt-to-income ratio of 500 percent or greater. ${ }^{5}$ Median Canadian household income in 2012 was $\$ 74,540$. So, a highly indebted household would have a mortgage on their primary dwelling of $\$ 370,000$ or more. On this basis, more than half a million households, or almost 11 percent of all mortgage-indebted households, were highly leveraged in 2012 - up from only 3.4 percent in 1999 (Table 3).

\section{Mortgages by Age}

Canadians of all ages are carrying larger mortgages than in the past. When the historical mortgage data are adjusted for inflation and presented in 2012 dollars, the increase is most pronounced in terms of carrying mortgage debt above the $\$ 200,000$ level (Figures 2-5).

The impact on leverage across age groups has been meaningful. For younger Canadians in the 25 to 34 age group, the mortgage debt-to- 


\section{Table 1: Value of Mortgages Held by Indebted Households, by Income Quintile}

Change in Share (Percentage Points) between 1999 and 2012, Adjusted for Inflation

\begin{tabular}{|c|c|c|c|c|c|c|}
\hline & Quintile1 & Quintile2 & Quintile3 & Quintile4 & Quintile5 & Total \\
\hline$\$ 1-\$ 14,999$ & -5.6 & -5.0 & -2.5 & -1.8 & -0.7 & -2.1 \\
\hline$\$ 15,000-\$ 49,999$ & -6.4 & -16.2 & -8.1 & -7.7 & -5.1 & -7.7 \\
\hline$\$ 50,000-\$ 99,999$ & -12.8 & -6.6 & -18.8 & -14.3 & -12.8 & -13.8 \\
\hline$\$ 100,000-\$ 199,999$ & 7.4 & 10.6 & 6.4 & -1.9 & -11.1 & -1.4 \\
\hline$\$ 200,000-\$ 299,999$ & 6.9 & 11.0 & 15.1 & 15.8 & 11.2 & 13.1 \\
\hline$\$ 300,000+$ & 10.6 & 6.3 & 7.9 & 9.9 & 18.6 & 11.9 \\
\hline \multicolumn{7}{|c|}{ Note: 1999 mortgages expressed in $\$ 2012$. } \\
\hline
\end{tabular}

\section{Table 2: Average Mortgage Debt to After-tax Income Ratio of Households with Mortgages, by} Income Quintile

\begin{tabular}{|c|c|c|c|}
\hline Quintile 1 (lowest) & 13.76 & 13.81 & 18.24 \\
\hline Quintile 2 & 2.48 & 2.85 & 4.03 \\
\hline Quintile 3 & 1.93 & 2.39 & 2.87 \\
\hline Quintile 5 (highest) & 1.13 & 1.29 & 1.55 \\
\hline Weighted Average of Households with Mortgages & 2.15 & 2.34 & 3.05 \\
\hline
\end{tabular}




\section{Table 3: Share of Indebted Households by Mortage-to-After-tax Income Ratio}

\begin{tabular}{|lccc|}
\hline \multicolumn{1}{|c}{ percent } & $\mathbf{1 9 9 9}$ & $\mathbf{2 0 0 5}$ & $\mathbf{2 0 1 2}$ \\
\hline$<=100$ & 33.3 & 30.5 & 24.6 \\
\hline $\mathbf{1 0 0 - 2 0 0}$ & 37.1 & 32.9 & 26.3 \\
\hline $\mathbf{2 0 0 - 3 0 0}$ & 16.9 & 19.0 & 21.7 \\
\hline $\mathbf{3 0 0 - 4 0 0}$ & 6.6 & 8.6 & 11.0 \\
\hline $\mathbf{4 0 0 - 5 0 0}$ & 2.5 & 3.4 & 5.6 \\
\hline$>=500$ & 3.4 & 5.5 & 10.8 \\
\hline
\end{tabular}

disposable income ratio has not only increased, but the share of young households with ratios above 300 percent has increased by almost 27 percentage points. These individuals are often first-time buyers. Accordingly, the larger mortgages and the increased leverage are likely the by-product of strong demand for home ownership despite the dramatic increase in home prices. Affordability has been maintained because of low debt financing costs, but it has left young Canadians with a considerable debt burden. There is a remarkable intergenerational effect taking place. Young real estate buyers are boosting home prices and real estate wealth for older homeowners, but are doing so by financing the purchases with ever greater debt.

Similar trends of higher debt and elevated mortgage debt-to-disposable income ratios are evident for older age groups, but the rise in debt ratios is less pronounced. This makes intuitive sense, since household income tends to rise with age, so home buyers will often have more financial resources when purchasing a primary dwelling.

Just like the distribution by income, the data show a rising trend of highly mortgage-indebted households across the age spectrum, with mortgage debt-to-disposable income ratios in excess of 500 percent. By this definition, roughly 14 percent of those of aged 25 to 34 and those of aged 35 to 44 are highly indebted. The share drops to 5 percent for those aged 45 to 54. But, the share of highly mortgage indebted jumps again to 9 percent for those 55 to 64 and climbs to 16 percent for those aged 65 to 74 . It is important to stress that these ratios were all dramatically lower in 1999 than in 2012.

The ratios do not suggest that the majority of Canadians have over indulged in debt, but it certainly highlights the fact that a significant portion of younger and older households are at greater financial risk from interest rate or income shocks.

\section{Mortgage Debt by Region}

Another key dimension is the changing regional distribution of mortgage debt. Mortgage debt-todisposable income ratios for mortgage-indebted households have climbed across the country, with Quebec being a notable exception. The regional centres with the strongest price and population increases showed the biggest increase in leverage, as new homeowners had to take on higher valued mortgages.

The provinces with the largest urban centres with the highest-priced real estate have experienced the most dramatic increases in mortgage debt-todisposable income ratios. Although these findings are not surprising, the ratio levels for Ontario and $\mathrm{BC}$ are eye opening. $\mathrm{BC}$ has gone from a primary mortgage-to-disposable income ratio of 250 percent in 1999 to 375 percent in 2012. Remember, that 375 percent is an average across mortgage-indebted households, meaning many are above this ratio. Similarly, Ontario has shot up from close to 200 percent to around 350 percent over the same time span. The Prairies have experienced a large jump in leverage and were above the 300 percent mark in 2012. Given these elevated regional ratios, the bulk of the population with mortgage 


\section{Figure 2: Distribution of Mortgage Debt for Households Aged 25-34}

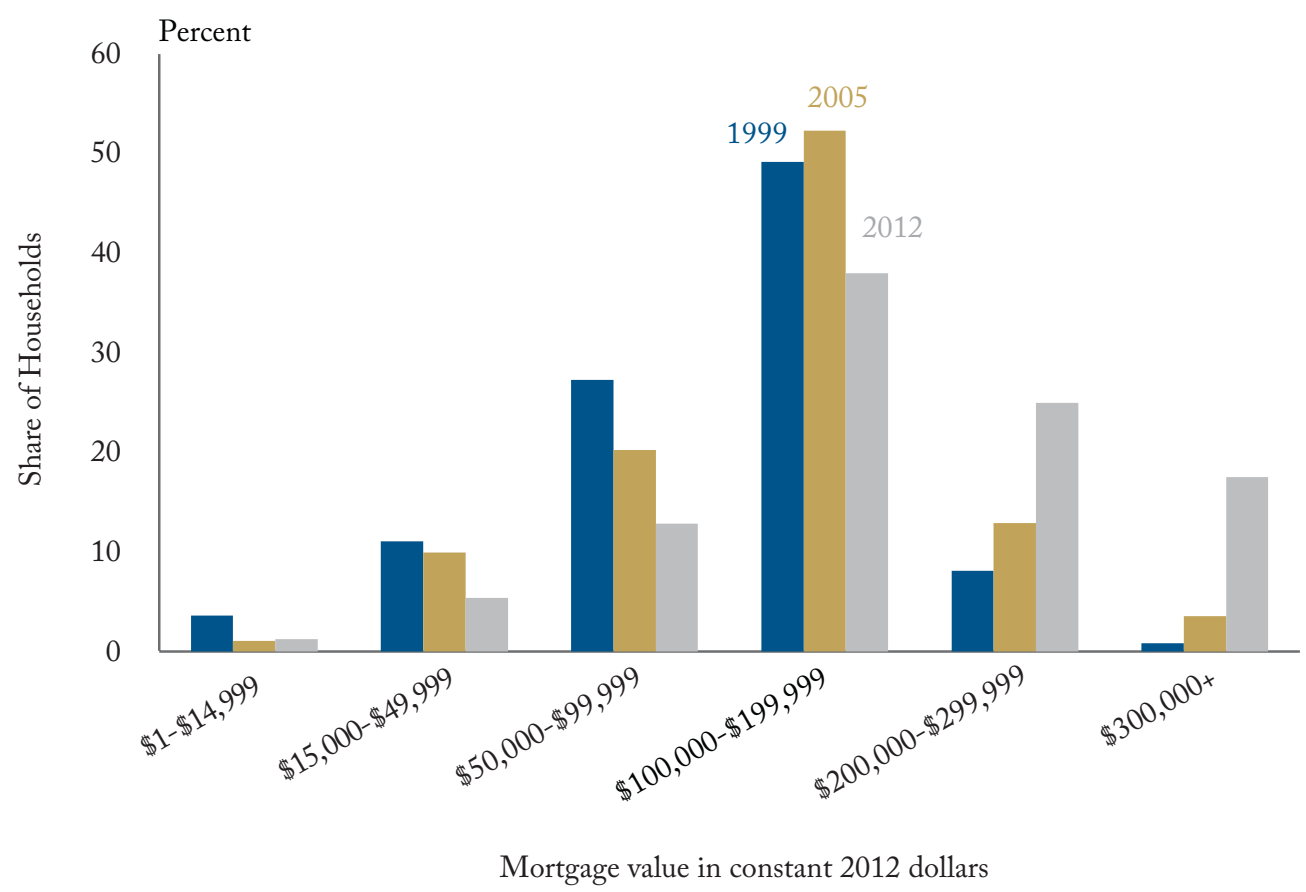

Figure 3: Distribution of Mortgage Debt for Households Aged 35-44

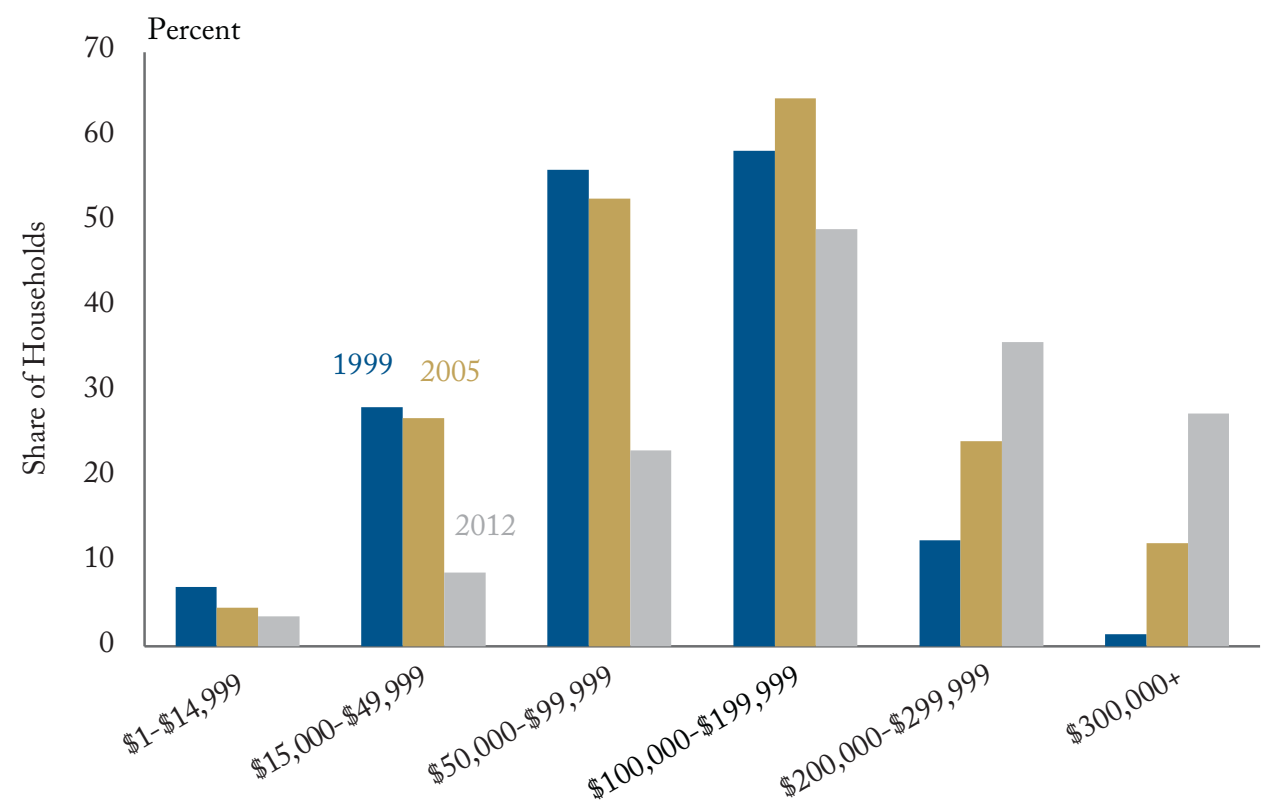

Mortgage value in constant 2012 dollars 


\section{Figure 4: Distribution of Mortgage Debt for Households Aged 45-54}

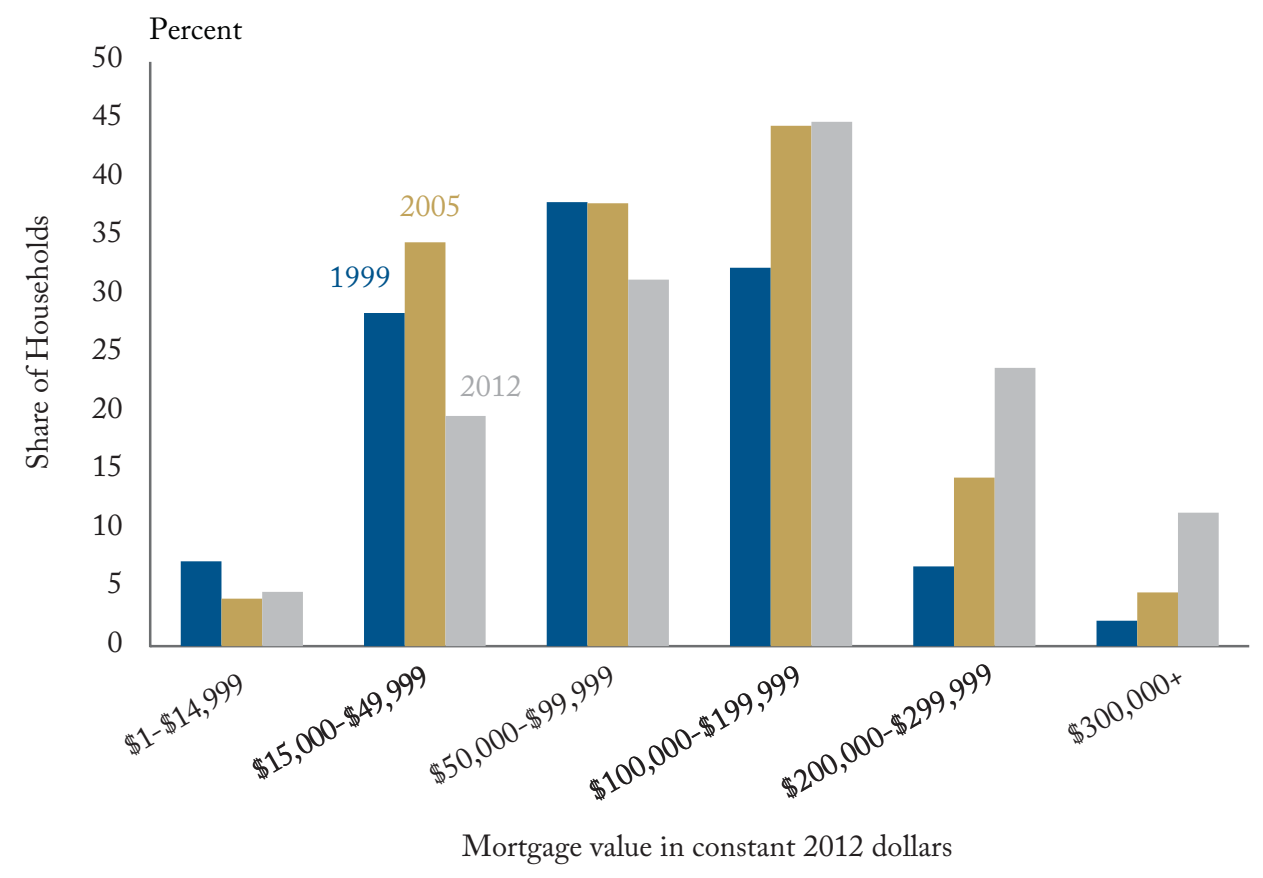

Figure 5: Distribution of Mortgage Debt for Households Aged 55-64

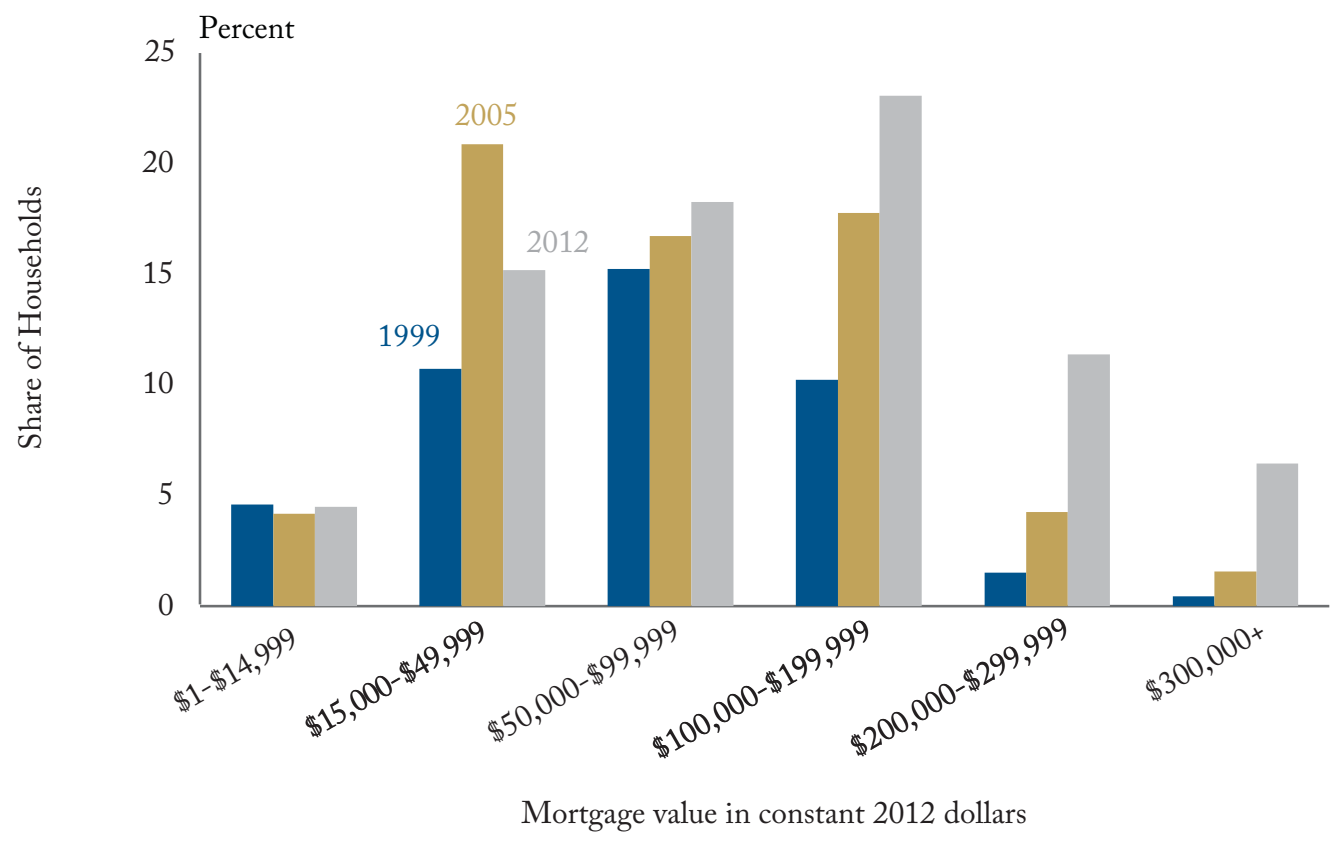

Source of Figure 4 and 5: Statistics Canada, SFS, 1999, 2005, 2012 - JCI. 


\section{Table4: Ratio of Mortgage Value to Total Assets}

\begin{tabular}{|llll|}
\hline Age Group & $\mathbf{1 9 9 9}$ & $\mathbf{2 0 0 5}$ & $\mathbf{2 0 1 2}$ \\
\hline $\mathbf{1 - 2 4}$ & 0.42 & 0.50 & 0.48 \\
\hline $\mathbf{2 5}-\mathbf{3 4}$ & 0.43 & 0.44 & 0.45 \\
\hline $\mathbf{3 5 - 4 4}$ & 0.31 & 0.32 & 0.35 \\
\hline $\mathbf{4 5}-\mathbf{5 4}$ & 0.22 & 0.24 & 0.24 \\
\hline $\mathbf{5 5}-\mathbf{6 4}$ & 0.19 & 0.18 & 0.20 \\
\hline $\mathbf{6 5 - 7 4}$ & 0.18 & 0.17 & 0.20 \\
\hline $75-999$ & 0.19 & 0.15 & 0.23 \\
\hline
\end{tabular}

Source: Statistics Canada, SFS, 1999, 2005, 2012 - JCI.

\section{Table 5: Flexible Financial Assets Relative to Mortgage Value (2012)}

\begin{tabular}{lc} 
None & 2.3 \\
\hline Less than $\$ 1500$ & 7.7 \\
\hline More than $\$ 1500$, less than $\$ 5000$ & 9.4 \\
\hline More than the value of the mortgage & 26.5 \\
\hline & \\
\hline &
\end{tabular}

debt more than five times annual income is largely located in these provinces, but it is worth noting the increase in all regions, except Quebec (Figure 6).

\section{Mortgage Leverage Shows Less of an Increase}

Up to this point, the focus has been on primary mortgage debt-to-disposable income ratios, because households use their after-tax income first to meet their financial obligations. However, leverage is another way of looking at the issue - and this has the advantage of comparing a stock of mortgage debt to a stock of assets. On this basis, mortgage leverage has increased for all age groups since 1999, but the increase has been quite modest. This could provide some comfort that the risks are less acute than the mortgage-to-income stats suggest.

However, many of the assets are relatively inflexible in the event that households have problems making payments. The single largest asset is the principal dwelling, which cannot be readily monetized, short of sale or the prior existence of a home equity line of credit that could be drawn upon. Another major asset is employer pension plan assets - but they often cannot be touched. The value of automobiles is also included in assets, but most Canadians need them for transport to work and they have high rates of depreciation. Accordingly, it is useful to look at the mortgages relative to the share of flexible financial assets (i.e., deposits, fixedincome investments, mutual funds, stocks, RRSPs, RIFs and TFSAs).

Again, in aggregate, Canadians appear to be in relatively good shape. For example, more than a quarter of mortgage holders have assets that can fully cover their mortgage liabilities and effectively have no risk. Of those that cannot cover the mortgage, many have savings that can help in the event of a significant disruption to income or higher debt service costs. However, almost 1 -in- 5 of all mortgage holders in 2012 had less than $\$ 5,000$ in financial assets to cover an income disruption or interest rate shock. Close to 1-in-10 of mortgaged households had less than $\$ 1,500$ in financial assets as a cushion to an adverse shock. This represents an inadequate financial buffer, as the Statistics Canada Survey of Household Spending indicates that the average mortgage payment for all households in 2012 was more than $\$ 1,000$ a month - and that is before taxes and operating costs.

The main point is that while net worth and measures of assets to liabilities look healthy in aggregate, there are significant pockets of 


\section{Figure 6: Average Mortgage Debt-to-Disposable Income Ratio of Households with Mortgages}

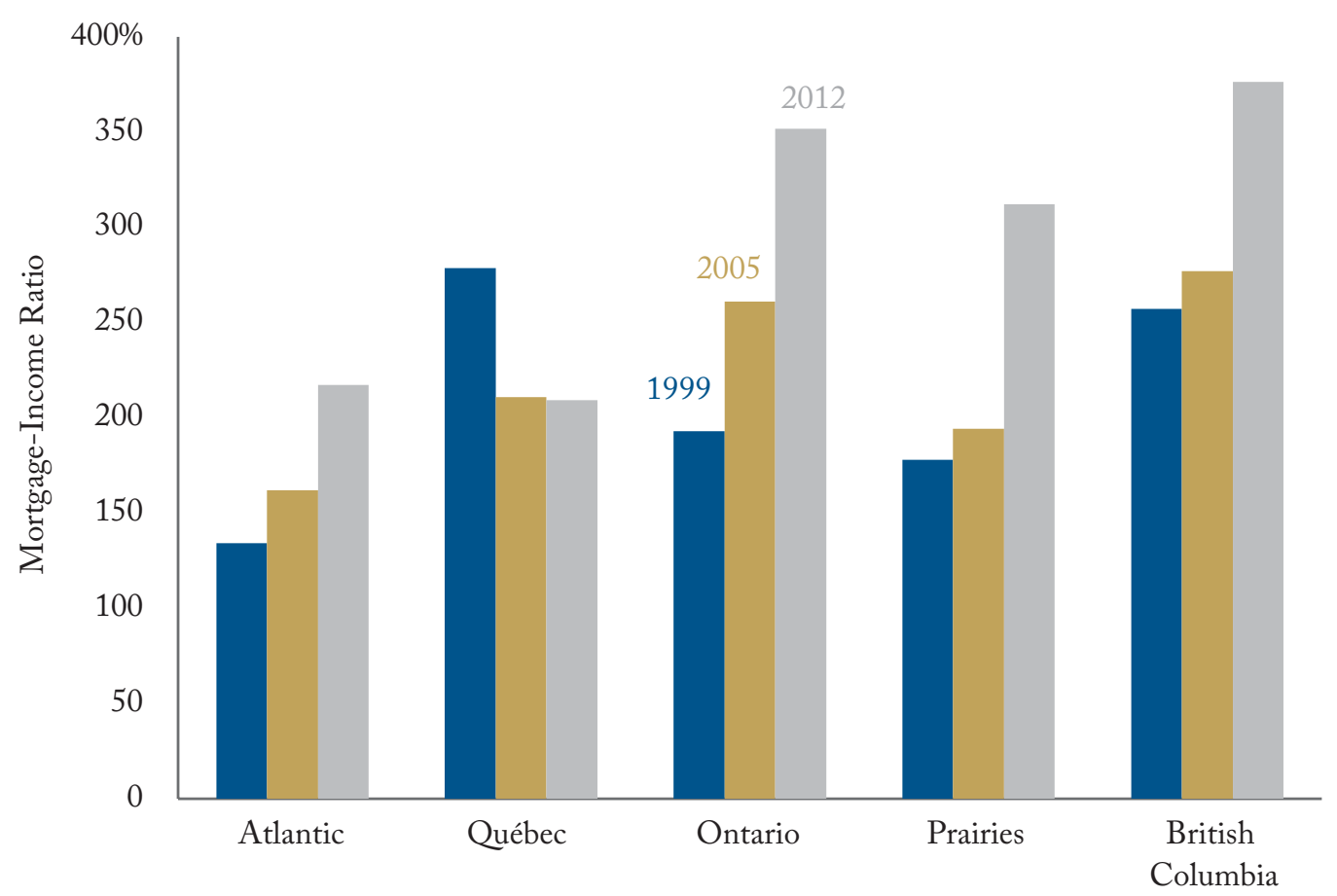

Source: Statistics Canada, SFS, 1999, 2005, 2012 - JCI.

vulnerability created by the growth in mortgage debt in recent years. Both the mortgage-to-income and the mortgage-to-flexible financial assets ratios suggest that at least 1 -in10 mortgage-indebted households are extremely vulnerable to a negative economic or financial shock.

\section{POLICY IMPLICATIONS}

The key message is that the distribution of debt is of critical importance when gauging the risk from the increase in household leverage. The data suggest that the majority of Canadians have been responsible in their borrowing, but the sustained low interest rate environment has encouraged a significant minority to take on considerably more mortgage debt relative to after-tax income. ${ }^{6}$ And, it is evident that there are particular pockets of excessive leverage or risk. Beyond risks related to mortgage default, higher debt-to-income ratios can pose economic risks as higher ratios have been associated internationally with larger falls in consumption during difficult economic times (Bank of England 2014, p. 9).

6 Beyond interest rates there have been a variety of factors contributing to the strength in real estate and mortgage borrowing, including population growth, urbanization, improving credit conditions, land-use restrictions to name just a few. 


\section{Figure 7: Share of Households Mortgages Debt-to-Income Ratio > 500 Percent}

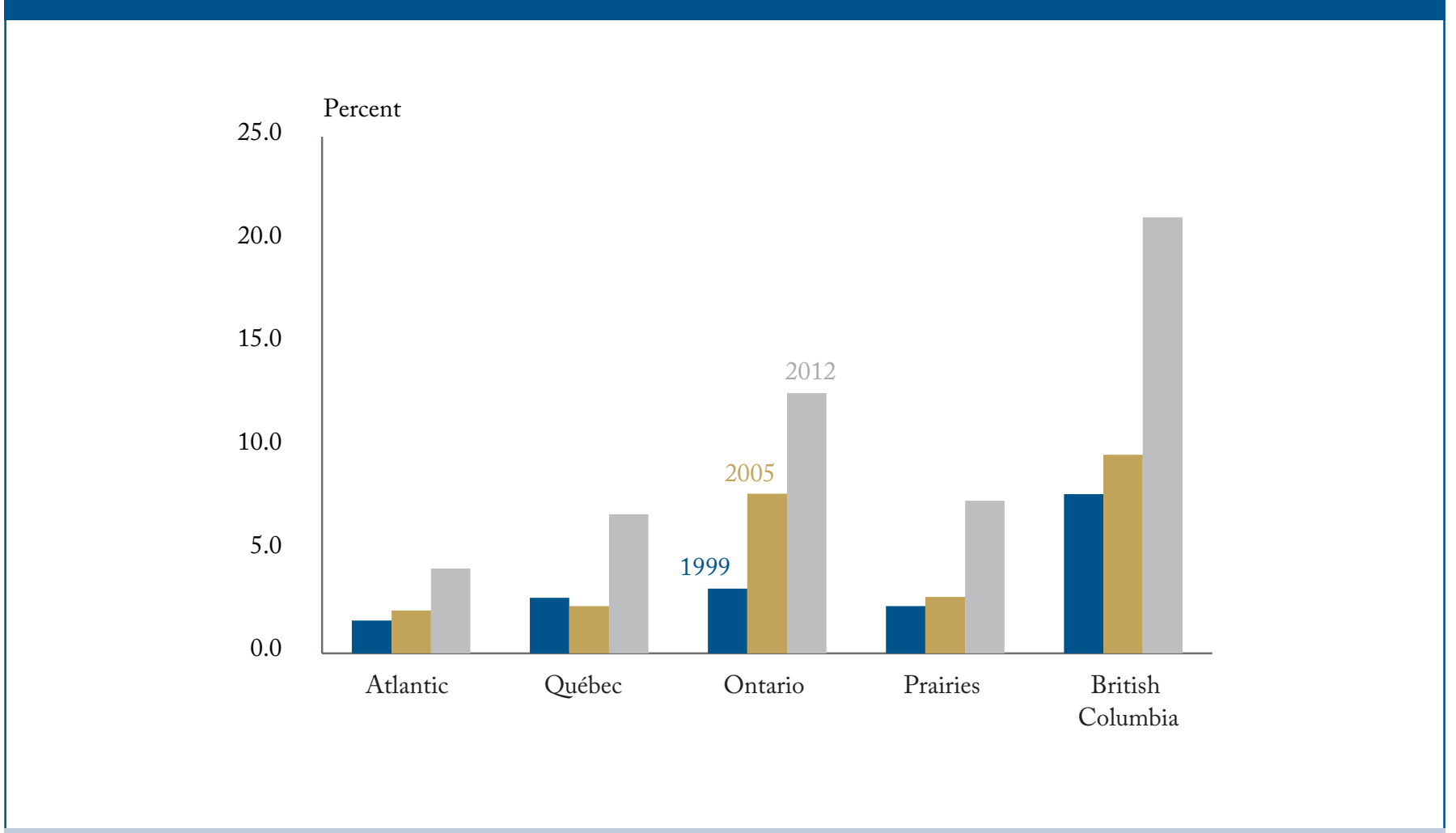

Source: Statistics Canada, SFS, 1999, 2005, 2012 - JCI.

These findings have a number of policy implications. First is a plea for more data and timely data on debt distribution. Although distributional debt data are available from a limited survey by Ipsos-Reid, there would be merit to a regular large-sample survey from Statistics Canada on debt trends to complement the National Balance Sheet Accounts. The lack of official public data weakens the public discourse about the economic and financial risks from household leverage. The SFS is useful, but given the last data points are for 2012, more information about trends in highly indebted households since then would be insightful. Indeed, a key issue is how the distribution of borrowers has changed in the wake of the mortgage insurance rule adjustments and the OSFI guidelines on residential mortgage underwriting practices in recent years.
So, making the SFS an annual survey would be valuable, as would distributional data on debt service costs.

This paper did not delve into the drivers behind Canada's hottest housing markets, which are clearly fueling greater mortgage borrowing in those cities, but the regional mortgage debt distribution data do suggest that many of the high mortgage debtto-disposable income ratio households are in the these urban centres. More information is needed to understand what actions would be most effective in keeping market conditions balanced. For example, data are required on the influence of foreign buyers in driving real estate prices in selected cities, such as Toronto and Vancouver, and the implications of land-use zoning. 
Second, although the distributional debt data show a rising share of heavily mortgage indebted households, it is important to acknowledge that the more timely National Balance Sheet mortgage data show that the regulatory tightening by OSFI and $\mathrm{CMHC}$ have constrained the pace of mortgage growth, which slowed to a pace more in line with income growth since 2013 (see Figure 8) (Schembri 2015). Since the tightning of regulations, there has also been a shift in originations away from high-ratio mortgages and towards more low-ratio mortgages, and an improvement in the distribution of credit scores at origination. These trends are consistent with research that shows that the tightening of mortgage insurance rules are effective at slowing growth in residential credit (Krznar and Morsink 2014). There is broad and international evidence that tighter lending constraints have been effective macroprudential policies (Cerutti, Claessens, and Laeven 2015).

So, the prior regulatory tightening looks to have been effective in leaning against mortgage debt growth during this prior of exceptionally low interest rates. However, the Bank of Canada has flagged a number of risks related to some of the underlying trends in the December 2014 and June 2015 Financial System Reviews. The Bank is very aware of the trend towards more highly indebted households, particularly young households. They noted a potential increase in uninsured mortgage originations by some households that are using other borrowing to manage their financial commitments and their spending. The Bank revealed a concern about an increase in the share of uninsured mortgages to riskier borrowers and an increase in sub-prime lending by non-OSFI regulated institutions. Since a cap was introduced on the National Housing Act Mortgage-Backed Securities program in 2013, the mortgage credit growth at less-regulated institutions has accelerated. Mortgage finance companies have increased their market share of residential mortgages in recent years, reaching 12 percent. More households have also been taking on mortgages with variable rates.

Given the effectiveness of the prior regulatory tightening, the jury is out on whether further regulatory action is required at this time. However, if the policymakers were to consider further measures to lean against the potential economic and financial risks of household mortgage debt, the distribution of debt does help to inform what options could be most beneficial. A heavy handed approach, such as raising the minimum down payment for all borrowers, would be a very blunt tool to address a distributional issue, so it is likely a suboptimal choice.

Targeted policies are available. For example, mortgage applications are assessed on a number of underwriting criteria, including credit scores, gross and total debt service ratios. These underwriting criteria could be further tightened. ${ }^{7}$ The guidelines for mortgage insurance (as summarized in Kwan, Geoffrey and Charan Sanghera. 2015) are that for credit scores less than 680 the gross debt service ratio is limited to 35 percent while those above 680 are limited to 39 percent. For total debt service ratios, those with credit scores of less than 680 are constrained to 42 percent and those with credit scores of more than 680 are limited to 44 percent. In other words, lenders do assess the risks to the mortgage loans, and the system has been successful at keeping mortgage default rates very low. If the

7 Gross debt service ratio includes: annual mortgage principal payments, annual mortgage interest payments, annual property taxes, annual heating costs, annual site lease (if appropriate) and 50 percent of annual condo fees (if applicable - which is then divided by gross annual income. Total debt service ratio is the same calculation but adding annual payments for all other debts to the numerator. (RBC Capital Markets 2015) 


\section{Figure 8: Mortgage Credit and Household Income}

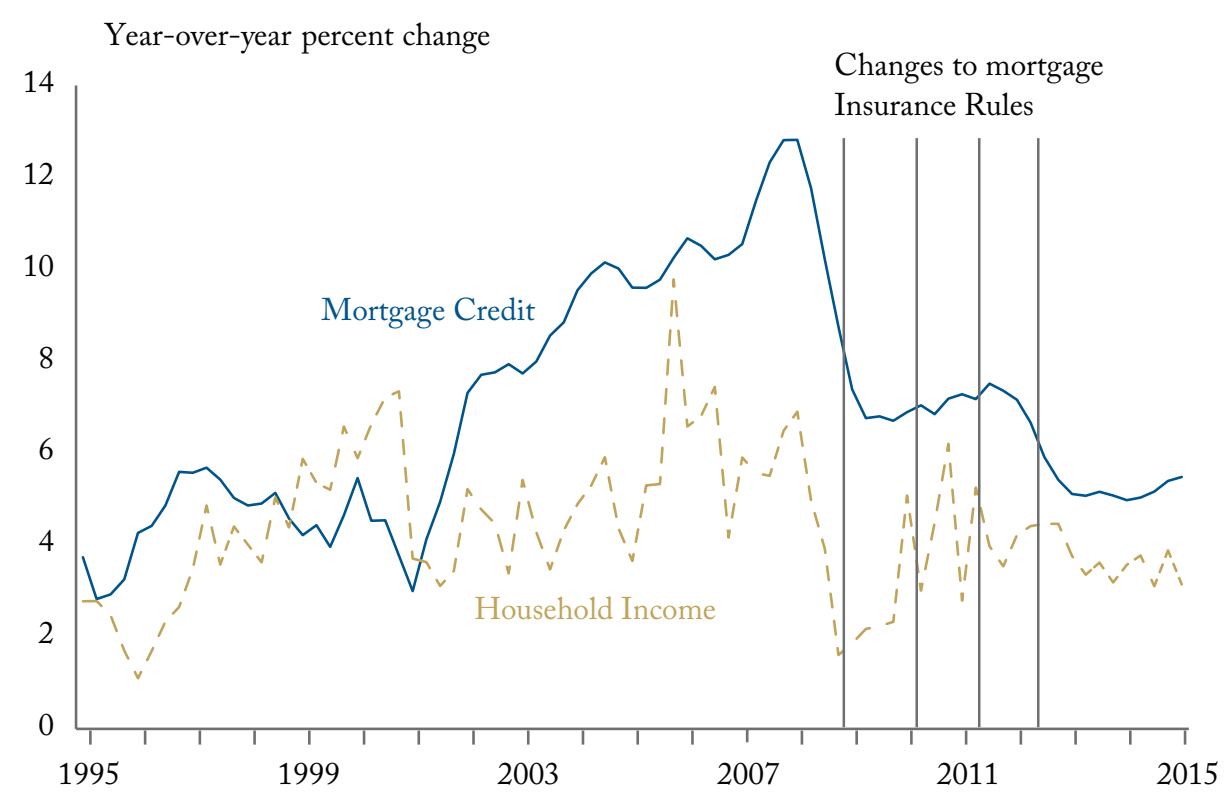

Sources: Haver Analytics, C.D. Howe Institute.

thresholds on credit scores were increased and/ or debt service ratio limits were lowered further, it would impact high leveraged borrowers the most.

Another approach could be to raise the minimum interest rate used in the income test for mortgage approvals. The federal government has already taken action on this front by requiring the use of the posted 5-year fixed mortgage rate on any income tests on insured mortgages with fixed interest rates and a term of less than five years and on mortgages at variable rates. Those taking a 5-year fixed mortgage are income tested on the 5 -year rate being transacted at. However, the level of 5-year posted mortgage rates is quite low and is likely to rise when monetary policy is eventually rebalanced. If mortgages were approved on the basis of income tests using interest rates a couple of percentage points higher than the 5-year posted rate today, borrowers would still benefit from the prevailing low rate environment, but households that could not meet their financial commitments in a higher rate environment would not have access to funding. Borrowers would also be incented to take on smaller mortgages in order to qualify. The impact of raising the qualifying interest rate is effectively the same as lowering the debt service ratio limits for underwriting, but could be a useful alternative approach.

The data suggest that there is a regional dimension to the most highly mortgage-indebted households, so policies could be aimed at addressing this aspect. In a sense, this would be the holy grail of policy measures, since it would target the most heated markets. However, it is hard to identify the optimal policy approach. Restrictions could be placed on foreign buying, but one would need to understand the influence of foreign buying, which we currently don't have adequate data on. Another 
policy example might be to vary the required down payment when taking on large mortgages or purchasing high-price homes, which would temper mortgage borrowing in the most expensive cities (like Toronto and Vancouver). The Bank of England provides an example from abroad. It adopted a limit on mortgages in 2014 so that lenders could not lend more than 15 percent of their total new residential mortgages at a loan-to-income ratio of 4.5 times or above (Bank of England 2014). This was interpreted as being partially targeted at the city of London where 19 percent of mortgages were above the 4.5 threshold, compared to 9 percent nationally. (The Telegraph 2014)

The acceleration of mortgage lending by non-OSFI regulated institutions should not be a problem, so long as the mortgages have been underwritten prudently. Accordingly, it would be useful to know if more high-leverage mortgage borrowers identified in this paper are being shifted into the lesser regulated areas of the financial system. If so, there could be some opportunity to prudentially tighten regulation in these channels.
Beyond the regulatory policy dimension, the increased share of highly indebted households does have some implications for monetary policy. At some point, the Bank of Canada will need to rebalance monetary policy. When this happens, the pace of tightening may need to be very gradual to limit the economic and financial risks. The impact of high household debt means that every quarter point rise in interest rates in the future will have a much bigger impact on household finances than in the past. Moreover, there is a psychological dimension, as the low rate environment has persisted for so long that many borrowers have come to see prevailing interest rates as normal. It will be a shock when monetary policy is ultimately rebalanced. It is also important to acknowledge that the low interest rate environment is keeping the price of debt extremely low. The implication is that the Bank of Canada should maintain its inflation targeting approach to monetary policy, but it should also look to raise interest rates when appropriate to reduce the incentive for households to take on higher debt loads. 


\section{REFERENCES}

Bank of Canada. 2014. "Assessment of Vulnerabilities and Risks.” Financial System Review. December

_- 2015. "Assessment of Vulnerabilities and Risks.” Financial System Review. June.

Bank of England. 2014. "Implementing the Financial Policy Committee's recommendation on loan to income ratios in mortgage lending" Consultation Paper, CP11/14.

Blackmore, Nicole. 2014. "Q\&A: How the new mortgage lending caps could affect you." The Telegraph.

Cerutti, E., S. Claessens, and L. Laeven. 2015. "The Use and Effectiveness of Macroprudential Policies: New Evidence." IMF Working Paper WP/15/61.

CMHC. 2013. "Demographic Change and the National Rate of Homeownership, 2001 to 2006.” CMHC Socio-economic Series 13-010.

Crawford, Allan, Cesaire Meh and Jie Zhou. 2013. "The Residential Mortgage Market in Canada: A Primer." Bank of Canada Financial System Review, December, 53-63.

Crawford, Allan, and Umar Faruqui. 2011."What Explains Trends in Household Debt in Canada?" Bank of Canada Review 2011-2012 (Winter): 3-15.

Faruqui, Umar, Xuezhi Liu, and Tom Roberts. 2012. "An Improved Framework for Assessing the Risks Arising from Elevated Household Debt." Bank of Canada Financial Stability Review, June, 51-57.
Krznar, Ivo, and James Morsink. 2014. "With Great Power Comes Great Responsibility: Macroprudential Tools at Work in Canada." IMF Working Paper.

Kwan, Geoffrey, and Charan Sanghera. 2015. "Canadian Mortgage Primer, 6th Edition”, RBC Capital Markets.

Mian, Atif R., Amir Sufi, and Emil Verner. 2015. "Household Debt and Business Cycles Worldwide." NBER, September 2015.

Schembri, Lawrence L. 2014. "Housing Finance in Canada: Looking Back to Move Forward.” National Institute Economic Review 230 (1): R45-57. doi:10.1177/002795011423000105.

2015. “The Long-Term Evolution of House Prices: An International Perspective" (Speech to the Canadian Association for Business Economics, Kingston, Ontario, 25 August 2015).

Tulk, David, and Andrew Kelvin. 2012. "A 2012 Primer of the Canadian Housing and Mortgage Market." TD Securities.

Walks, Alan, and Brian Clifford. 2015. "The Political Economy of Mortgage Securitization and the Neoliberalization of Housing Policy in Canada." Environment and Planning A 47 (8): 1624-42. doi:10.1068/a130226p. 


\section{ReCEnt C.D. Howe Institute Publications}

December 2015 Laurin, Alexandre. "Shifting the Federal Tax Burden to the One-Percenters: A Losing Proposition.” C.D. Howe Institute E-Brief.

December 2015 Hale, Geoffrey, and Yale Belanger. From "Social Licence" to "Social Partnership": Promoting Shared Interests for Resource and Infrastructure Development. C.D. Howe Institute Commentary 440.

November 2015 Found, Adam, Peter Tomlinson, and Benjamin Dachis. "Business Tax Burdens in Canada's Major Cities: The 2015 Report Card.” C.D. Howe Institute E-Brief.

November 2015 Alexander, Craig, and Alexandre Laurin. "Tax Reform Priorities for Canada: Creating More Income to Go Around?" C.D. Howe Institute E-Brief.

November 2015 Dachis, Benjamin, and William B.P. Robson. Building Better Budgets: Canada's Cities Should Clean Up their Financial Reporting. C.D. Howe Institute Commentary 439.

November 2015 Veillard, Jeremy, Omid Fekri, Irfan Dhalla, and Niek Klazinga. Measuring Outcomes in the Canadian Health Sector: Driving Better Value from Healthcare. C.D. Howe Institute Commentary 438.

October 2015 Anand, Anita. "The Future of Poison Pills in Canada: Are Takeover Bid Reforms Needed?" C.D. Howe Institute E-Brief.

October 2015 Aragón, Fernando M. “The Effect of First Nations Modern Treaties on Local Income.” C.D. Howe Institute E-Brief.

October 2015 Blomqvist, Åke, and Colin Busby. "Feasible Pharmacare in the Federation: A Proposal to Break the Gridlock." C.D. Howe Institute E-Brief.

October 2015 Richards, John, with Mark Krass. First Nations Own-Source Revenue: How Is the Money Spent? C.D. Howe Institute Commentary 437.

Octobre 2015 Ambler, Steve, et Craig Alexander. "Un pour cent? Vraiment? Ce que la théorie économique moderne laisse présager quant au rendement futur des investissements.” Institut C.D. Howe Cyberbulletin.

October 2015 Ambler, Steve, and Craig Alexander. "One Percent? For Real? Insights from Modern Growth Theory about Future Investment Returns.” C.D. Howe Institute E-Brief.

\section{SUPPORT THE INSTITUTE}

For more information on supporting the C.D. Howe Institute's vital policy work, through charitable giving or membership, please go to www.cdhowe.org or call 416-865-1904. Learn more about the Institute's activities and how to make a donation at the same time. You will receive a tax receipt for your gift.

\section{A REPUTATION FOR INDEPENDENT, NONPARTISAN RESEARCH}

The C.D. Howe Institute's reputation for independent, reasoned and relevant public policy research of the highest quality is its chief asset, and underpins the credibility and effectiveness of its work. Independence and nonpartisanship are core Institute values that inform its approach to research, guide the actions of its professional staff and limit the types of financial contributions that the Institute will accept.

For our full Independence and Nonpartisanship Policy go to www.cdhowe.org. 

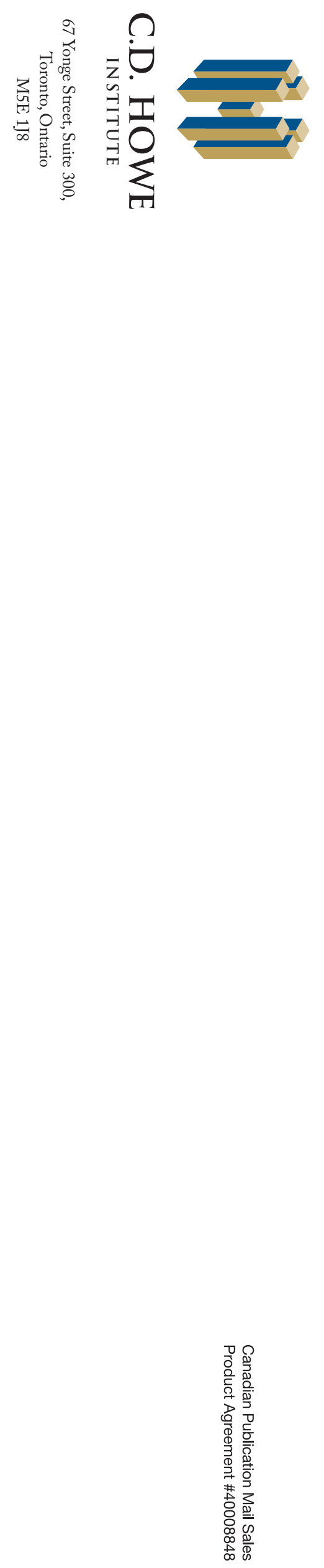